Letrônica, Porto Alegre, v. 7, n. 2, p. 917-933, jul./dez., 2014

\title{
VIAGENS DE CAIM: \\ UMA ANÁLISE CRONOTÓPICA DO ROMANCE DE JOSÉ SARAMAGO
}

\author{
CAIN'S TRAVELS: \\ A CHRONOTOPIC ANALYSIS FROM JOSÉ SARAMAGO'S NOVEL
}

\author{
Suéllen Rodrigues Ramos da Silva* \\ Siméia de Castro Ferreira Neve** \\ Vanessa Riambau Neves Pinheiro***
}

\begin{abstract}
Resumo: Neste artigo, realizamos uma cronotopoanálise do romance Caim (2009), de José Saramago, obra que se constitui enquanto releitura de episódios bíblicos do Velho Testamento estruturada a partir da errância do protagonista em viagens que ocorrem por meio de transgressões espaço-temporais. Nossas reflexões partem do conceito de cronotopo (BAKHTIN, 1998), considerando a indissociabilidade das categorias espaço e tempo, que abordamos em momentos distintos deste estudo em uma separação apenas metodológica. A análise permite-nos observar o deslocamento de caim entre espaços realistas e imaginativos (BORGES FILHO, 2009) e entre tempos distintos, "outros presentes", transgressões temporais que se refletem na estruturação narrativa (REIS; LOPES, 1988).

Palavras-chave: Cronotopo; Espaço; Tempo; Transgressão; Caim.
\end{abstract}

\begin{abstract}
This paper aims to do a chronotope analysis of Cain's novel (2009) written by José Saramago, which is considered a rereading of Old Testament biblical episodes. The analyzed novel is structured upon the wanderings of the protagonist on his trips that occur through spatiotemporal transgressions. This paper intents to provide a reflection based on chronotope concept accordingly to Bakhtin (1998), that considers the inseparability of time and space categories. At the present study we suggest this time separation only to a methodological purpose. We have observed from the phenomena analysis the Cains' displacement between realistic and imaginative spaces (BORGES FILHO, 2009) as well as between distinct times - other times - temporal transgressions, that the narrative structure is based on them (REIS; LOPES, 1988).
\end{abstract}

Keywords: Chronotope; Space; Time; Transgression; Cain.

\footnotetext{
* Doutoranda vinculada ao Programa de Pós-graduação em Letras (PPGL) pela Universidade Federal da Paraíba (UFPB). É Mestre em Letras, tendo defendido a dissertação Artur e Santiago: relações entre jornalismo narrativo e cinema-documentário (UFPB, 2014). É bacharel em Comunicação Social, habilitação em Jornalismo (UFPB, 2007). E-mail: suellenrodrigues.rs@gmail.com

** Mestranda vinculada ao PPGL pela UFPB. Bolsista CAPES. Possui Licenciatura em História pela Universidade Estadual Vale do Acaraú (UVA) e Licenciatura Plena em Letras, habilitação Língua Portuguesa (UFPB). E-mail: sdcastro7@hotmail.com

*** Doutora pelo Programa de Pós-Graduação em Letras da Universidade Federal do Rio Grande do Sul (UFRGS), Área de Literaturas de Língua Portuguesa. É professora Adjunta de Literatura na UFPB. É autora do livro Portugal e a geração da apatia (UFPB, 2013). E-mail: vanessanrp@hotmail.com
} 
No romance Caim (2009), José Saramago faz uma releitura de acontecimentos bíblicos do Velho Testamento, a partir da criação literária ficcional, retratando a errância do protagonista em viagens que ocorrem por meio de transgressões espaçotemporais. Devido à importância central de tais transgressões, que constituem um elemento estruturante da narrativa, optamos por estudar as viagens de caim ${ }^{1}$ sob a perspectiva de uma cronotopoanálise.

Para Bakhtin (1998, p. 211), o cronotopo é a "interligação fundamental das relações temporais e espaciais, artisticamente assimiladas em literatura". Termo empregado pelas ciências matemáticas, fundamentado na teoria da relatividade de Einsten, é transportado para a crítica literária "quase como uma metáfora (quase, mas não totalmente); nele é importante a expressão de indissolubilidade de espaço e de tempo", entendendo-se o cronotopo como "categoria conteudística-formal da literatura".

As características de espaço e tempo também são tratadas por Osman Lins (1987, p. 63) como indissociáveis ao estudarmos tais categorias na análise do texto literário. 0 referido autor vê a narrativa com um "objeto compacto", no qual "todos os fios", portanto, os diferentes componentes narrativos, "se enlaçam entre si e cada um reflete todos os outros", sendo "artificial" o isolamento de cada categoria quando nos dispomos a estudá-las, o que é feito apenas metodologicamente.

A estrutura deste estudo segue tal entendimento. Apesar de concordamos com a visão de Lins, semelhante a dos autores Carlos Reis e Ana Cristina Lopes (1988, p. 208), que também apontam a estreita articulação entre tempo e espaço, fazendo referência ao conceito bakhtiniano de "cronotopo", ordenamos nossa análise privilegiando, num primeiro momento, o estudo das transgressões espaciais em Caim, e, em seguida, abordando questões relativas à categoria tempo.

Observamos que as viagens realizadas pelo protagonista dão-se entre espaços realistas e ambientes imaginativos e/ou fantasistas (BORGES FILHO, 2009), em deslocamentos através de outros "presentes", transgressões temporais que se refletem na narrativa, estruturada pela imbricação de tempos de naturezas distintas, e são reveladas pelo narrador, que assume uma postura de intervenção direta e constante na construção do enredo.

\footnotetext{
${ }^{1}$ Merece ênfase que em nosso estudo usaremos nomes próprios em minúsculas, de acordo com a forma utilizada no romance saramaguiano, e inicial maiúscula quando se tratar de referência à narrativa bíblica.
} 
Borges Filho (2008) propõe um estudo do espaço relacionado à composição literária. Segundo o teórico, a topoanálise tem em vista toda e qualquer espacialidade representada na obra de ficção. 0 autor utiliza a terminologia proposta por Bachelard (1989); entretanto, diverge com relação à definição, pretendendo ampliar o alcance de sentido. Desta forma, disserta sobre algumas das mais relevantes funções do espaço, além das relações entre espaço e enredo, conceituando-o do ponto de vista da topoanálise, como:

um conceito amplo que abarcaria tudo o que está inscrito em uma obra literária como tamanho, forma, objetos e suas relações. Esse espaço seria composto de cenário e natureza. A idéia de experiência, vivência, etc., relacionada ao conceito de lugar segundo vários estudiosos, seria analisada a partir da identificação desses dois espaços sem que, para isso, seja necessário o uso da terminologia 'lugar'. Dessa maneira, não falaríamos de lugar, mas de cenário ou natureza e da experiência, da vivência das personagens nesses mesmos espaços (BORGES FILHO, 2008, p. 1).

Na narrativa de Saramago, com relação à representação do espaço, o protagonista contempla as três gradações propostas por Borges Filho (2008), ou seja, em Suas viagens, caim oscila entre espaços realistas - que se assemelham à realidade cotidiana; imaginativos - espaços que não existem no mundo real; e fantasistas - espaços que divergem da realidade e possuem suas próprias regras (BORGES FILHO, 2008, p. 3).

Sobre a apresentação inicial do romance, vemos que o enredo se desenvolve, no capítulo 1, em um único espaço, ou seja, no jardim do éden, também chamado "paraíso terrestre" e "floresta do universo" (SARAMAGO, 2009, p. 11). 0 narrador descreve o lamentável esquecimento de deus que criou adão e eva desprovidos do uso da fala.

No capítulo 2, expulsos do jardim do éden, adão e eva vagueiam em busca de abrigo e fixam moradia em uma "estreita caverna, em verdade mais cavidade que caverna, de tecto baixo, descoberta num afloramento rochoso ao norte do jardim do éden" (SARAMAGO, 2009, p. 18).

No capítulo 3, é descrita a habitação própria de adão e eva, além da apresentação do espaço de convívio familiar. A fraternidade entre os irmãos caim e abel é evidenciada, bem como a distinção de seus afazeres.

Cedo se viu que as vocações dos dois pequenos não coincidiam. Enquanto abel preferia a companhia das ovelhas e dos cordeiros, as alegrias de caim iam todas para as enxadas, as forquilhas e as gadanhas, um, fadado para abrir o caminho na pecuária, outro, para singrar na agricultura (SARAMAG0, 2009, p. 27-28). 
Essa diferença de tarefas acaba provocando sérias desavenças, pois deus aceita a oferta de abel e rejeita a de caim, culminando no homicídio de abel e o castigo de caim, como veremos no esquema a seguir:

Fig. 1 - Sequência dos fatos (do homicídio de abel ao castigo divino)

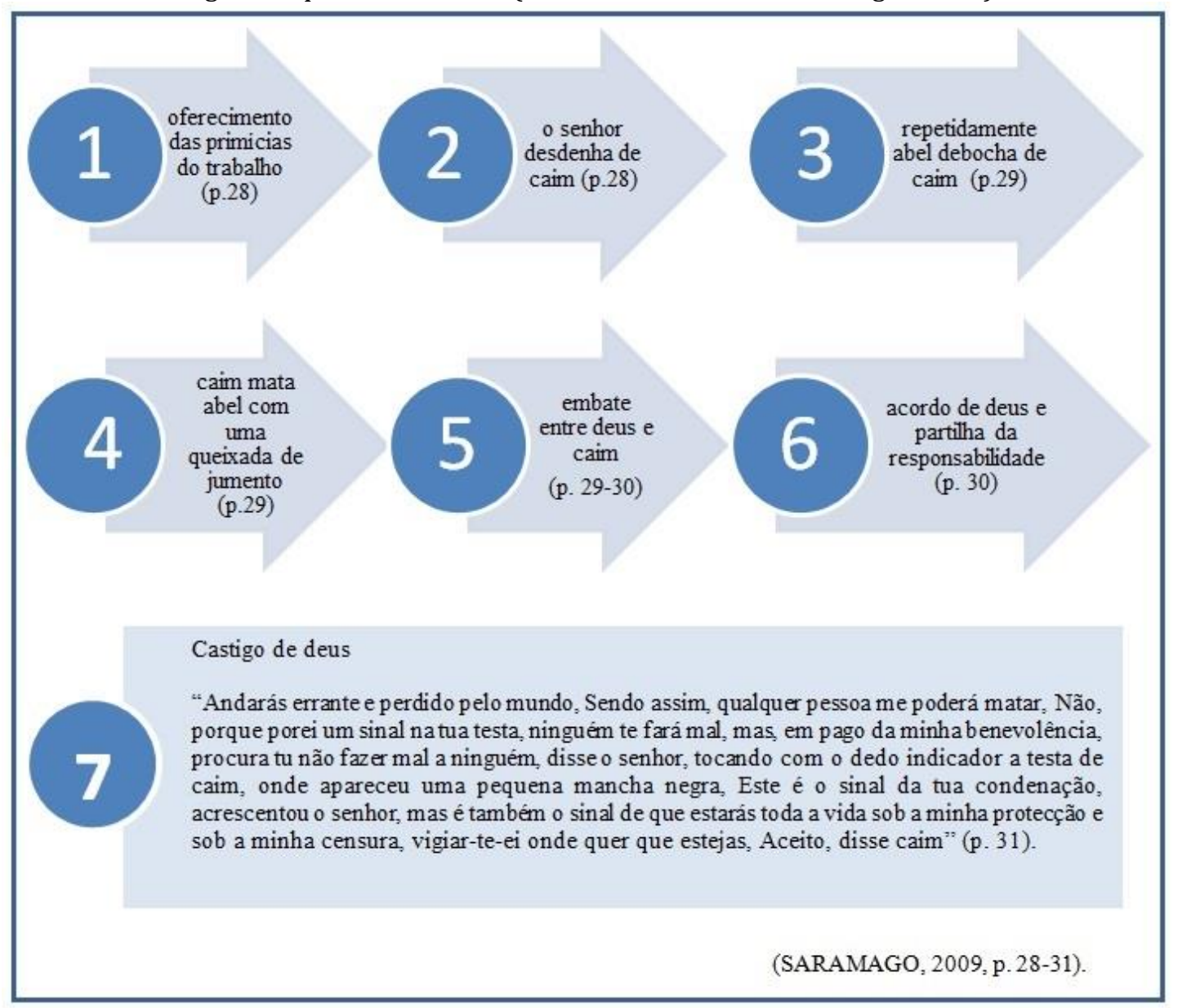

A partir dos acontecimentos evidenciados, constatamos que o motivo principal das viagens de caim ocorre devido ao homicídio de abel, que finda com o castigo divino. Dentre as movimentações do protagonista, há uma recorrência de deslocamentos que transgridem o espaço, provocando uma mudança espacial que gradativamente sai da esfera realista e alterna para ambientes imaginativos e/ou fantasistas.

Ao caminhar por alguns dias (capítulo 5), caim, que veio do poente (oeste), encontra um velho que levava duas ovelhas atadas em uma corda e este o direciona para a terra de nod, cuja senhora chamava-se lilith e seu marido noah. Segundo a descrição bíblica, a terra de Node, lugar de peregrinação, ficava a leste do Éden (Gn 4.16). 
Ainda no capítulo 5, caim está na terra de nod e, no término deste, parte do palácio e continua a sua peregrinação.

Depois de virar a próxima esquina deixaria de ver o palácio. 0 velho das ovelhas não estava ali, o senhor, se era ele, dava-lhe carta branca, mas nem um mapa de estradas, nem um passaporte, nem recomendações de hotéis e restaurantes, uma viagem como as que faziam antigamente, à ventura, ou, como já então se dizia, ao deus-dará. Caim tocou outra vez o jumento e em pouco tempo encontrou-se em campo aberto. (SARAMAGO, 2009, p. 63).

Nesse momento, há uma mudança na paisagem e caim migra para o que Borges Filho (2008) denominaria de espaço fantasista.

Fig. 2 - Mudança na paisagem (indeterminação espacial)

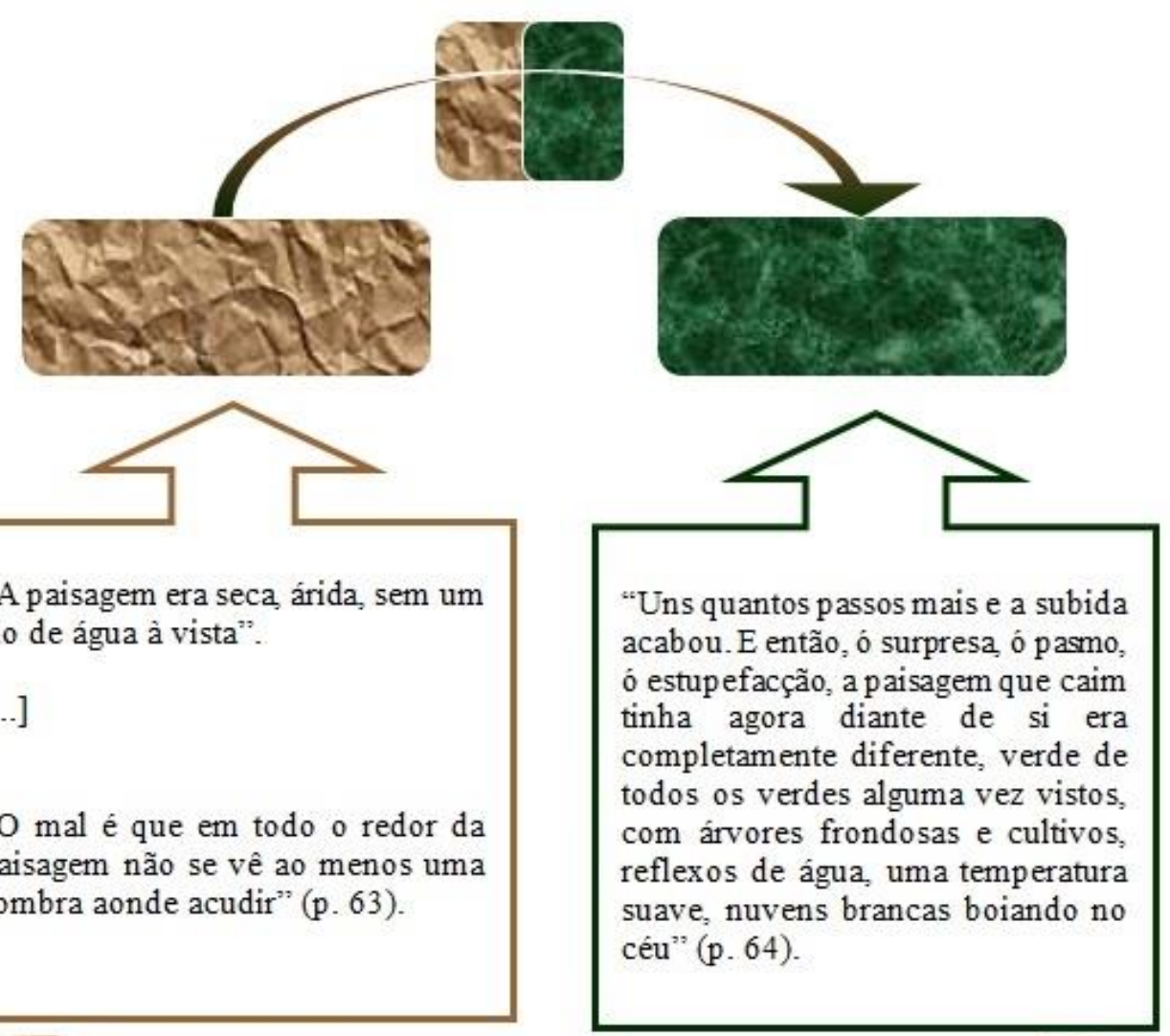

"Olhando para trás, a mesma aridez de antes a mesma secura, ali nada havia mudado. Era como se existisse uma fronteira, um traço a separar dois paises, $\mathrm{Ou}$ dois tempos, disse caim sem consciência de havê-lo dito, o mesmo que se alguém 0 estivesse pensando em seu lugar" (p. 64).

(SARAMAGO, 2009, p. 63-64). 
Como destacado no esquema, caim depara-se com uma dupla espacialidade. Em seguida, viaja no tempo e encontra-se com abraão. Conforme a descrição bíblica, nesse contexto de nascimento e infância de Isaque, Abraão habitava em Berseba, terra dos filisteus (Gn 21: 31-34).

Após salvar isaac de ser sacrificado pelo pai abraão, devido às ordens do senhor, caim desperta nas proximidades da torre de babel.

Estou a sonhar, disse também caim quando abriu os olhos. Havia adormecido em cima do jumento e de repente despertou. Estava no meio de uma paisagem diferente, com algumas árvores raquíticas dispersas e tão seca como a terra de nod, porém seca de areia, não de cardos. Outro presente, disse. Pareceu-lhe que este devia ser mais antigo que o anterior, aquele em que havia salvo a vida ao rapazito chamado isaac, e isto mostrava que tanto poderia avançar como voltar no tempo, e não por vontade própria, pois, para falar francamente, sentia-se como alguém que mais ou menos, só mais ou menos, sabe onde está, mas não aonde se dirige (SARAMAGO, 2009, p. 69-70).

Na narrativa bíblica, a Torre de Babel foi construída nas proximidades da planície de Sinear, na Babilônia (Gn 11: 2 e 8).

Ao contemplar a obra inacabada da torre de babel, caim vê o alvoroço e recrimina a decisão de deus de interromper a construção. Logo após, faz nova viagem.

Sem precisar do estímulo dos calcanhares do cavaleiro arrancou [o jumento] num trote vivo e logo num galope em tudo inesperados, vista a sua natureza asinina, de animal seguro mas a quem, em princípio, não se podia pedir pressa. Os assaltantes tiveram de resignar-se a vê-lo desaparecer no meio de uma nuvem de pó, a qual viria a ter outra importante consequência, a de fazer passar caim e a sua montada a outro presente futuro neste mesmo lugar (SARAMAG0, 2009, p. 72-73, acréscimo nosso).

Ao sair, possivelmente, da região da Babilônia, caim encontra-se com abraão. Logo após, deus, abraão e caim rumam para sodoma (SARAMAG0, 2009, p. 76).

Num instante, aquele mesmo caim que havia estado em sodoma e voltara aos caminhos encontrou-se no deserto do sinai onde, com grande surpresa, se viu no meio de uma multidão de milhares de pessoas acampadas no sopé de um monte [...] Uma coisa já era certa, o nome de um tal de moisés andava na boca de toda a gente, uns com antiga veneração, com certa impaciência recente a maioria (SARAMAGO, 2009, p. 82).

Após esse evento, nova transgressão espacial ocorre: "O lugar é o mesmo, mas o presente mudou. Caim tem diante dos olhos a cidade de jericó, onde, por razões de segurança militar, não lhe haviam permitido que entrasse" (SARAMAGO, 2009, p. 91). 
Caim sai de jericó e depara-se com um lugar desconhecido ou, quem sabe, um espaço imaginativo: “Caim não sabe onde se encontra, não percebe se o jumento o estará levando por uma das tantas vias do passado ou por algum estreito carreiro do futuro, ou se, simplesmente vai andando por um qualquer outro presente que ainda não se deu a conhecer" (SARAMAGO, 2009, p. 102).

Caim agora, guiado pelo jumento, regressa ao palácio de lilith:

Sem precisar de que lho ordenassem, o jumento avançou para a porta do palácio e aí se deteve. Caim deixou-se escorregar da albarda, entregou a arreata a um escravo que tinha acudido e perguntou-lhe, Está alguém no palácio, Sim, está a senhora, Vai dizer-lhe que chegou um visitante, Abel, chamas-te abel, murmurou o escravo, lembro-me bem de ti, Vai, então (SARAMAGO, 2009, p. 104).

Ao sair de nod, caim chega a terra de us cujo proprietário é job:

De súbito, viu-se a entrar pela porta de uma cidade onde nunca havia estado. Imediatamente pensou que não levava um cêntimo consigo nem via modo imediato de o conseguir, uma vez que ali ninguém o conhecia [...] Os homens olharam-no de alto a baixo, não lhe encontraram pinta de mendigo ou de vagabundo, só se detiveram um nada a olhar-lhe a marca da testa, e o segundo disse, 0 proprietário mais rico destes sítios e de todo o oriente chama-se job, vai pedir-lhe que te dê trabalho, talvez tenhas sorte (SARAMAGO, 2009, p. 110).

Quando caim deixa a terra de us, pouco andou e viu-se "rodeado de verdejantes montanhas, de luxuriosos vales onde discorriam riachos da mais pura e cristalina água que os olhos humanos alguma vez haviam visto e a boca saboreado. Isto, sim, poderia ter sido o jardim do éden de saudosa memória" (SARAMAGO, 2009, p. 121).

Nessa nova saída, encontra-se com noé na construção da barca:

Caim resolveu deixar-se de rodeios e atacou, E isto que estão a fazer, que é, um barco, uma arca, uma casa, perguntou. 0 mais velho do grupo, um homem alto, robusto como sansão, limitou-se a dizer, Casa não é, E arca também não, cortou caim, porque não há arca sem tampa, e a tampa desta, se existisse, não haveria força humana que conseguisse levantar. 0 homem não respondeu e fez menção de se retirar, mas caim reteve-o no último instante, Se não é casa nem arca, então só pode ser um barco, disse, Não respondas, noé, disse a mais velha das mulheres, o senhor irá ficar enfadado contigo se falares mais do que a conta (SARAMAGO, 2009, p. 122).

No último capítulo, aparentemente, as errâncias de caim terão um desfecho: "Fosse como fosse, porém, a grande viagem aproximava-se do fim, era tempo de começar a preparar a conclusão, o desembarque ou o que tiver de suceder" (SARAMAGO, 2009, p. 141). 
Mikhail Bakhtin (1998, p. 211) destaca o tempo, em literatura, enquanto "o princípio condutor do cronotopo". Borges Filho (2011, p. 60) discorda da visão do teórico russo, considerando que não se justifica a hierarquização entre as categorias espaço e tempo na concepção de tal conceito.

\begin{abstract}
Pensamos mais numa relação dialética e equânime entre essas duas categorias. Com efeito, já os gregos afirmaram que nada existe fora das categorias de espaço e de tempo. Se imaginarmos alguém ou algo, esse ser obrigatoriamente estará situado em algum lugar em determinado tempo. Mesmo que essas categorias não apareçam explicitamente em algum trecho do texto literário, elas são sempre pressupostas. Além disso, por uma questão de lógica, a ideia de indissociabilidade pressupõe a igualdade de importância entre espaço e tempo. (BORGES FILHO, 2011, p. 60).
\end{abstract}

Apesar de não descartarmos a validade das ponderações feitas por Borges Filho, abordamos neste estudo com maior detalhamento a categoria tempo por esta apresentar grande rendimento na análise desta obra a partir de diferentes perspectivas devido à imbricação de tempos de naturezas distintas na estruturação da narrativa, não desconsiderando um estudo posterior, mais verticalizado na observação da categoria espaço, que pode ainda ser abordada sob outros aspectos além dos já apontados.

Retratando episódios do Velho Testamento, o tempo bíblico, que demonstra progressão cronológica, distinto do nosso tempo histórico, é referenciado, principalmente, no início do enredo, inclusive com ponderações do narrador.

\begin{abstract}
Ponto de ordem à mesa. Antes de prosseguirmos com esta instrutiva e definitiva história de caim a que, com nunca visto atrevimento, metemos ombros, talvez seja aconselhável, para que o leitor não se veja confundido por segunda vez com anacrónicos pesos e medidas, introduzir algum critério na cronologia dos acontecimentos. Assim faremos, pois, começando por esclarecer alguma maliciosa dúvida por aí levantada sobre se adão ainda seria competente para fazer um filho aos cento e trinta anos de idade. A primeira vista, não, se nos ativermos apenas aos índices de fertilidade dos tempos modernos, mas esses cento e trinta anos, naquela infância do mundo, pouco mais teriam representado que uma simples e vigorosa adolescência que até o mais precoce dos casanovas desejaria para si. Além disso, convém lembrar que adão viveu até aos novecentos e trinta anos, pouco lhe faltando, portanto, para morrer afogado no dilúvio universal, pois finou-se em dias da vida de lamec, o pai de noé, futuro construtor da arca. (SARAMAGO, 2009, p. 12-13).
\end{abstract}

A partir do fragmento, notamos que o narrador evidencia sua posição de ser aquele que conduz a história e dirige-se diretamente ao leitor, postura adotada em vários momentos do romance. Em tom didático, distingue do tempo histórico, no qual 
ele e o leitor estão inseridos, o tempo bíblico, em que adão, aos 130 anos, teria seu primeiro filho, caim.

O narrador ainda alerta o leitor para as possíveis anacronias que podem surgir caso esse tempo da história, que, em Caim, possui uma natureza mítica, seja visto a partir das referências temporais contemporâneas.

Nova ponderação a ser feita a partir do trecho destacado é que o tempo de vida do personagem adão, 930 anos, findando-se já "em dias de vida de lamec, o pai de nóe, futuro construtor da arca" (SARAMAGO, 2009, p. 13), é uma referência ao último marco do tempo diegético, considerando que, após diversas transgressões cronotópicas, a história protagonizada por caim avança até o término do dilúvio bíblico.

Em outro momento do romance, o narrador dirige-se mais uma vez ao leitor com o intuito de esclarecer o que poderia, também, ser considerado anacronismo, chamando a atenção para a deliberada atualização da linguagem narrativa. Nitidamente, suspende a descrição da cena em que caim, após conversar com o velho que caminha com duas ovelhas amarradas a um baraço, dirige-se à cidade de nod.

\begin{abstract}
Enquanto o falso abel vai andando em direcção à praça onde, no dizer do velho, se encontrará com o seu destino, atendamos à pertinentíssima observação de alguns leitores vigilantes, dos sempre atentos, que consideram que o diálogo que acabámos de registar como acontecido não seria historicamente nem culturalmente possível, que um lavrador de poucas e já nenhumas terras, e um velho de quem não se conhecem ofício nem benefício, nunca poderiam pensar e falar assim. Têm razão esses leitores, porém, a questão não estará tanto em dispor ou não dispor de ideias e vocabulário suficiente para as expressar, mas sim na nossa própria capacidade de admitir, que mais não seja por simples empatia humana e generosidade intelectual, que um camponês das primeiras eras do mundo e um velho com duas ovelhas atadas a um baraço, apenas com o seu limitado saber e uma linguagem que ainda estaria a dar os primeiros passos, fossem impelidos pela necessidade a provar maneiras de expressar premonições e intuições aparentemente fora do seu alcance. Que eles não disseram aquelas palavras, é mais do que óbvio, mas as dúvidas, as suspeitas, as perplexidades, os avanços e recuos da argumentação, estiveram lá. 0 que fizemos foi simplesmente passar ao português corrente o duplo e para nós irresolúvel mistério da linguagem e do pensamento daquele tempo. Se o resultado é coerente agora, também o seria na altura porque, ao final, almocreves somos e pela estrada andamos. Todos, tanto os sábios como os ignorantes. (SARAMAGO, 2009, p. 39-40).
\end{abstract}

É possível estendermos tal reflexão a distintas passagens da narrativa, pseudoanacronismos presentes no romance que só se tornam construções plausíveis a partir da ponderação do narrador a respeito da deliberada atualização da linguagem. Um exemplo é a fala do personagem adão, que diz não poder cavar nem lavrar a terra por lhe faltarem 
“a enxada e o arado" (SARAMAG0, 2009, p. 23), ferramentas às quais não poderia conhecer sendo o primeiro e único homem existente na terra, ou mesmo, as reflexões do narrador sobre nod, ao afirmar ter sido exagero chamá-la de cidade, pois

qualquer cidade que se preze desse nome nunca se reconhecerá na cena primitiva que temos diante dos olhos, faltam aqui os automóveis e os autocarros, os sinais de tráfego, os semáforos, as passagens subterrâneas, os anúncios nas frontarias ou nos telhados das casas, numa palavra, a modernidade, a vida moderna. (SARAMAG0, 2009, p. 40).

Está, portanto, evidenciado na própria obra, por uma opção estilística de seu autor, o tempo histórico no qual se insere. A referência a um dado temporal do universo não ficcional, alusiva ao mundo externo à obra, encontra-se também em outras passagens do romance, a exemplo da menção feita logo após set, o terceiro filho de adão e eva, ser citado:

Ao terceiro, como também ficou dito, chamaram-lhe set, mas esse não entrará na narrativa que vamos compondo passo a passo com melindres de historiador, por isso aqui o deixamos, só um nome e nada mais. Há quem afirme que foi na cabeça dele que nasceu a ideia de criar uma religião, mas desses delicados assuntos já nos ocupámos avonde no passado, com recriminável ligeireza na opinião de alguns peritos, e em termos que muito provavelmente só virão a prejudicar-nos nas alegações do juízo final quando, quer por excesso quer por defeito, todas as almas forem condenadas. (SARAMAG0, 2009, p. 13, grifo nosso).

0 trecho em destaque é uma referência de Saramago à polêmica causada a partir da publicação do livro O evangelho segundo Jesus Cristo (1991), obra anterior, também de sua autoria, que se constitui como recriação ficcional paródica dos episódios bíblicos do Novo Testamento.

Percebe-se, portanto, que o narrador situa o momento de sua narração na contemporaneidade. É principalmente a partir desse tempo presente, compartilhado com o seu leitor, que retoma aquelas narrativas bíblicas a fim de recontá-las. Tal percepção leva-nos à divisão de tempo bastante difundida em estudos de teoria narrativa enquanto tempo da história e tempo do discurso, tempo da enunciação e tempo do enunciado ou mesmo tempo do narrado e tempo do narrar.

O confronto existente entre os dois planos temporais, ou seja, o discurso, ou tempo do narrar a história, e o vivido, ou tempo do narrado, considerando a transmissão dos eventos passados via voz presente, constitui elemento importante da teorização sobre o tempo, sendo referido por Borges Filho (2011) a partir de reflexões de Irene 
Machado. Esse "confronto", portanto, dá-se em Caim, entre o presente contemporâneo, tempo do discurso, no qual se posiciona o narrador, e o tempo bíblico, diegético, no qual se dão os acontecimentos. Contudo, o tempo da narrativa não transcorre de forma linear. Durante a sua trajetória, o protagonista não apenas transita entre diversos espaços, mas também em tempos, épocas diferentes.

Concordamos com a visão de Borges Filho (2011) a respeito da impossibilidade de hierarquizar a importância do tempo enquanto categoria superior ao espaço na análise cronotópica, principalmente ao focarmos as especificidades de Caim. No romance, a própria estrutura narrativa aponta para o estudo associativo das duas categorias devido às constantes transgressões de espaço e tempo, ocorrendo repentinamente, sem que o protagonista provoque-as, tenha controle sobre elas ou ao menos compreenda de que modo sucedem.

Já nos momentos finais do romance, durante a construção da arca que abrigaria a família de noé e os pares de animais, por ocasião do dilúvio, caim tem um diálogo com deus que em nada esclarece a natureza de suas viagens:

Não me disseste que vieste aqui fazer, disse deus, Nada de especial, senhor, aliás não vim, encontrei-me cá, Da mesma maneira que te encontraste em sodoma ou nas terras de us, E também no monte sinai, e em jericó, e na torre de babel, e nas terras de nod, e no sacrifício de isaac, Tens viajado muito, pelos vistos, Assim é, senhor, mas não que fosse por minha vontade, pergunto-me até se estas constantes mudanças que me têm levado de um presente a outro, ora no passado, ora no futuro, não serão também obra tua, Não, nada tenho que ver com isso, são habilidades primárias que me escapam, truques para épater le bourgeois, para mim o tempo não existe, Admites então que haja no universo uma outra força, diferente e mais poderosa que a tua, É possível, não tenho por hábito discutir transcendências ociosas, mas uma coisa ficas sabendo, não poderás sair deste vale, nem te aconselho que o tentes, a partir de agora as saídas estarão guardadas, em cada uma delas haverá dois querubins com espadas de fogo e com ordem de matar quem quer que se aproxime (SARAMAGO, 2009, p. 124).

Apesar da afirmação divina sobre a permanência de caim no vale, em meio à conversa com dois anjos, dá-se uma súbita transgressão cronotópica do personagem:

Não me admira, começou caim a dizer, mas a frase ficou-lhe no ar, suspensa, enquanto uma espécie de vento lhe açoitava os ouvidos e de repente se encontrou no interior de uma tenda. Havia um homem deitado, nu, e esse homem era noé a quem a embriaguez submergira no mais profundo dos sonos. Havia outro homem que com ele estava a ter trato carnal e esse homem era cam, o seu filho mais novo, pai, por sua vez, de canaã [...] Quando noé acordar e perceber o insulto que lhe havia sido feito por cam, dirá, fazendo cair sobre o filho dele a maldição que ferirá todo o povo cananeu [...] Caim já ali não estará, o mesmo rápido sopro de vento o trouxe à porta da arca no preciso momento 
em que se vinham acercando noé e o seu filho cam com as últimas notícias, Partimos amanhã, disseram, os animais já estão todos na arca, os comestíveis armazenados, podemos levantar ferro. (SARAMAGO, 2009, p. 131-132).

Assim como ocorre sobre a relação entre o tempo do discurso e o tempo da história, mais uma vez, o próprio narrador situa o leitor a respeito da natureza do tempo em seu romance, pronunciando-se sobre as transgressões temporais que acontecem na trajetória de caim.

O narrador direciona a interpretação do leitor para a percepção de que não haveria uma ida ao passado ou ao futuro, mas, sim, o fluxo do presente em que se encontrava o protagonista para um "outro presente", estimulando a compreensão de que caim estaria em uma espécie de "presente contínuo", o que poderíamos aproximar de uma suspensão temporal.

No fragmento a seguir, é possível observar o posicionamento do narrador sobre as transgressões cronotópicas vividas pelo protagonista:

\begin{abstract}
Olhou para trás, a mesma aridez de antes, a mesma secura, ali nada havia mudado. Era como se existisse uma fronteira, um traço a separar dois países, Ou dois tempos, disse caim sem consciência de havê-lo dito, o mesmo que se alguém o estivesse pensando em seu lugar. Levantou a cabeça para olhar o céu e viu que as nuvens que se moviam na direcção donde viemos se detinham na vertical do chão e logo desapareciam por desconhecidas artes. [...] Bem, tudo isso pode ser certo, mas o que ninguém me explica é a razão de as nuvens não poderem passar de lá para cá. A não ser, diz a voz que fala pela boca de caim, que o tempo seja outro, que esta paisagem cuidada e trabalhada pela mão do homem tivesse sido, em épocas passadas, tão estéril e desolada como a terra de nod. Então estamos no futuro, perguntamos nós, é que temos visto por aí uns filmes que tratam do assunto, e uns livros também. Sim, essa é a fórmula comum para explicar algo como o que aqui parece ter sucedido, o futuro, dizemos nós, e respiramos tranquilos, já lhe pusemos o rótulo, a etiqueta, mas, em nossa opinião, entender-nos-íamos melhor se lhe chamássemos outro presente, porque a terra é a mesma, sim, mas os presentes dela vão variando, uns são presentes passados, outros presentes por vir, é simples, qualquer pessoa perceberá. (SARAMAGO, 2009, p. 64-65).
\end{abstract}

Além da ideia de trânsito de caim a partir de um "presente contínuo", a obra abriga ainda uma trajetória cíclica do personagem, iniciada em sua saída da terra de nod, quando engravida lilith, o que representaria o "término" de seu tempo naquele espaço:

Qualquer um diria que a paz social e a paz doméstica reinavam finalmente no palácio, a todos envolvendo no mesmo amplexo fraternal. Não era assim, decorridos alguns dias caim havia chegado à conclusão de que, agora que lilith estava à espera de um filho, o seu tempo terminara. (SARAMAGO, 2009, p. 59). 
Após percorrer diversos outros tempos e espaços, "outros presentes", caim inicia um trajeto de retorno à cidade de nod. 0 transcorrer do tempo é sinalizado por meio da descrição das mudanças espaciais a partir da degradação de um dos lugares em que caim esteve:

Caim passou por aqui, isso sim, é certo. Vai descobri-lo quando de súbito lhe aparecer o que resta da casa arruinada onde em tempos se resguardou da chuva e onde não poderia abrigar-se hoje porque o que ainda havia de tecto caiu já, agora não se vêem mais que uns troços de muros esboroados que, com a passagem de mais dois ou três invernos, definitivamente se confundirão com o chão onde se erguiam, terra que tornou à terra, pó que tornou ao pó. (SARAMAGO, 2009, p. 103).

O período que o protagonista esteve fora da cidade de nod, aproximadamente dez anos, é posto na narrativa a partir da informação da idade de enoch, seu filho, representando uma demarcação cronológica linear na diegese.

O escravo subiu a escada e voltou daí a pouco acompanhado por um rapazinho que devia ter uns nove ou dez anos, É o meu filho, pensou caim. [...] Que andaste a fazer durante todos estes anos, foi a pergunta e caim respondeu, Vi coisas que ainda não aconteceram, Queres dizer que adivinhaste o futuro, Não adivinhei, estive lá, Ninguém pode estar no futuro, Então não lhe chamemos futuro, chamemos-lhe outro presente, outros presentes, Não percebo, Também a mim ao princípio me custou a compreender, mas depois vi que, se estava lá, e realmente estava, era num presente que me encontrava, o que havia sido futuro tinha deixado de o ser, o amanhã era agora, Ninguém vai acreditar em ti, Não penso dizer isto a mais ninguém, 0 teu mal é que não trazes contigo nenhuma prova, um objecto qualquer desse outro presente, Não foi um presente, mas vários (SARAMAGO, 2009, p. 104-106).

A passagem de caim por esses "vários presentes" não segue a ordem de sucessão dos acontecimentos bíblicos do Velho Testamento. Apesar de sabermos que a Bíblia não está organizada em sequência cronológica, e, sim, temática, o enredo de Caim só atende à disposição que está no livro sagrado até o início da errância do protagonista, não havendo mais correspondência entre a ordem de sucessão dos eventos quando se iniciam as transgressões cronotópicas.

Então caim contou a lilith o caso de um homem chamado abraão a quem o senhor ordenara que lhe sacrificasse o próprio filho, depois o de uma grande torre com a qual os homens queriam chegar ao céu e que o senhor com um sopro deitou abaixo, logo o de uma cidade em que os homens preferiam ir para a cama com outros homens e do castigo de fogo e enxofre que o senhor tinha feito cair sobre eles sem poupar as crianças, que ainda não sabiam o que iriam querer no futuro, a seguir o de um enorme ajuntamento de gente no sopé de um monte a que chamavam sinai e a fabricação de um bezerro de ouro que adoraram e por isso morreram muitos, o da cidade de madian que se atreveu a matar trinta e seis soldados de um exército denominado israelita e cuja 
população foi exterminada até à última criança, o de uma outra cidade, chamada jericó, cujas muralhas foram deitadas abaixo pelo clamor de trombetas feitas de cornos de carneiro e depois destruído tudo o que tinha dentro, incluindo, além dos homens e mulheres, novos e velhos, também os bois, as ovelhas e os jumentos. (SARAMAGO, 2009, p. 106-107).

Pela ordem linear do texto bíblico, teríamos primeiro a narração da construção da arca e a ocorrência do Dilúvio (Gn 6-9), que no momento dessa conversa entre lilith e caim ainda não aconteceu no romance saramaguiano. Posteriormente, a conquista de Jericó pelo povo hebreu liderada por Josué, auxiliar de Moisés (Gn 10); a construção da Torre de Babel (Gn 11: 1-8); a destruição de Sodoma e Gomorra (Gn 19); a provação de Abraão para sacrifício do seu filho Isaque (Gn 22); a construção do bezerro de ouro pelo povo liderado por Arão quando Moisés está no Monte Sinai (Gn 32); a vingança contra os midianitas (Nm 31); e a provação pela qual passa Jó (Jó 3).

E não apenas no caminhar de caim através dos diversos espaços pelos quais transita desde a saída de junto de sua família, ao assassinar o irmão abel, até deixar a arca, após o dilúvio que atinge toda a terra, não há uma linearidade temporal, partindo, neste caso, do referencial bíblico. Na estruturação do romance, também são perceptíveis momentos de suspensão do tempo diegético, progressão ou mesmo antecipação de informações, notando-se a utilização de recursos variados para a construção do texto literário.

Observa-se o uso de prolepses, quando há um "movimento de antecipação, pelo discurso, de eventos cuja ocorrência, na história, é posterior ao presente da ação" (REIS\&LOPES, 1988, p. 283), a exemplo do momento em que noah, marido de lilith, reflete sobre a possibilidade de matar sua mulher e caim, o amante preferido dela: "Mato-os, insistia noah, ampliando agora o seu propósito, mato-o a ele e mato-a a ela. Sonhos, fantasias, delírios, noah não matará ninguém e terá ele próprio a sorte de escapar à morte sem fazer nada por isso". (SARAMAG0, 2009, p. 52, grifo nosso).

A narrativa abriga ainda diversas elipses, formas "de suspensão de lapsos temporais mais ou menos alargados, supressão essa que é denunciada de modo variavelmente transparente" (REIS\&LOPES, 1988, p. 243):

Caim já entrou, já dormiu na cama de lilith, e, por mais incrível que nos pareça, foi a sua própria falta de experiência de sexo que o impediu de se afogar no vórtice de luxúria que num só instante arrebatou a mulher e a fez voar e gritar como possessa. Rangia os dentes, mordia a almofada, logo o ombro do homem, 
cujo sangue sorveu. [...] Nem na segunda, nem na terceira, nem em todas as que se seguiram. (SARAMAGO, 2009, p. 51).

Além desses pontos de aceleração da narração dos acontecimentos, também registramos em Caim movimentos temporais de retorno, "destinados a relatar eventos anteriores ao presente da ação e mesmo, em alguns casos, anteriores ao seu início" (REIS\&LOPES, 1988, p. 230). O romance possui analepses externas, nas quais o momento da narração é suspenso e há um retorno a um tempo anterior ao começo da história, como a ocasião em que o narrador conta uma passagem da infância de caim:

E, contudo, esse homem acossado que aí vai, perseguido pelos seus próprios passos, esse maldito, esse fratricida, teve bons princípios como poucos. Que o diga sua mãe que tantas vezes o foi encontrar, sentado no chão húmido do horto, a olhar para uma pequena árvore recém-plantada, à espera de vê-la crescer. Tinha quatro ou cinco anos e queria ver crescer as árvores. Então, ela, pelos vistos ainda mais imaginosa que o filho, explicou-lhe que as árvores são muito tímidas, só crescem quando não estamos a olhar para elas, É que lhes dá vergonha, disse-lhe um dia. Por alguns instantes caim permaneceu calado, a pensar, mas logo respondeu, Então não olhes, mãe, de mim não têm vergonha, estão habituadas. Prevendo já o que viria depois, a mãe apartou o olhar e imediatamente a voz do filho soou triunfal, Agora mesmo cresceu, agora mesmo cresceu, eu bem te tinha dito que não olhasses. Nessa noite, quando adão voltou do trabalho, eva, rindo, contou-lhe o que se tinha passado e o marido respondeu, Esse rapaz vai longe. Talvez fosse, sim, se o senhor não se tivesse atravessado no seu caminho. (SARAMAGO, 2009, p. 33).

As analepses interiores, de retorno a algo que aconteceu na diegese, ou seja, resgatando um momento anterior, mas que faz parte do enredo, também são estruturas utilizadas nessa obra de Saramago:

Que vai você fazer, velho malvado, matar o seu próprio filho, queimá-lo, é outra vez a mesma história, começa-se por um cordeiro e acaba-se por assassinar aquele a quem mais se deveria amar, Foi o senhor que o ordenou, foi o senhor que o ordenou, debatia-se abraão, Cale-se, ou quem o mata aqui sou eu, desate já o rapaz, ajoelhe e peça-lhe perdão, Quem é você, Sou caim, sou o anjo que salvou a vida a isaac. (SARAMAGO, 2009, p. 63, grifo nosso).

O narrador, mesmo situando-se a partir do nosso presente, em determinadas ocasiões, parece posicionar-se dentro da cena, do presente diegético, como se fosse ele uma testemunha ocular dos acontecimentos:

Os cadáveres dos facinorosos ficarão pendurados ali mesmo onde se encontram até que deles não restem mais que os ossos, pois a sua carne é maldita, e a terra, se nela fossem sepultados, se revolveria em transe até vomitá-los, uma e muitas vezes. Nessa noite, lilith e caim dormiram juntos pela última vez. (SARAMAGO, 2009, p. 61, grifo nosso). 
Coloca-se como testemunha, mas continua evidenciando sua postura de condutor da história, narrando a partir daquele presente, mas demonstrando conhecimento a respeito do que irá acontecer a seguir.

No capítulo final do romance, caim sai da arca e conta para deus sobre a morte de noé e de todos os demais. De acordo com o narrador, a voz de deus nem chega a ser ouvida, perde-se a fala seguinte de caim e sabe-se apenas que argumentaram um contra o outro, continuaram e ainda estão a discutir. Na última frase do romance, "A história acabou, não haverá nada mais que contar" (SARAMAGO, 2009, p. 142), demonstra ainda mais o controle total do narrador.

Os resultados e as discussões aqui apresentadas evidenciam o estudo da obra saramaguiana Caim, mais especificamente as transgressões cronotópicas realizadas pelo protagonista. Com relação aos resultados obtidos a partir do panorama geral das transgressões espaciais, vimos que, no romance, há uma predominância de espaços realistas nos capítulos 1 a 5 e uma alternância de ambientes imaginativos e/ou fantasistas (BORGES FILHO, 2009) nos capítulos subsequentes.

Conforme exposto, em suas inúmeras viagens o protagonista transporta-se para outros espaços e outros tempos, anteriores ou posteriores ao que se encontrava, entendidos como "outros presentes" e dispostos na narrativa ficcional em ordenação própria, distinta das referências bíblicas.

As transgressões temporais também ocorrem no âmbito da estrutura narrativa, com o uso de recursos diversos. Estando ausente no romance uma explicação para as transgressões cronotópicas, que não seriam provocadas nem por caim nem por deus, consideramos ser aceitável atribuí-las à forte intervenção da instância narrativa. Observamos isso pelo modo como o narrador defende abertamente o protagonista, ataca os posicionamentos de deus, coloca em evidência a sua função de condutor do enredo ao relatar o que descreve como "a definitiva história de caim" (SARAMAGO, 2009, p. 13), uma narrativa com "regras" predeterminadas (p. 104) que vão sendo esclarecidas para o leitor ao longo da obra.

Assim se dá com as relações entre o tempo bíblico e o tempo histórico, o tempo do narrador e o tempo do narrar, os pseudoanacronismos presentes no texto e o claro posicionamento do narrador a partir dos "tempos modernos" (SARAMAG0, 2009, p. 13), que servem como referencial para a sua opção pela atualização da linguagem. 
O narrador, ao colocar-se em cena, parece, em certa medida, assumir-se enquanto personagem, inserindo-se no enredo em uma posição de onisciência, onipresença e onipotência que supera a do personagem deus, retratado em Caim como uma entidade repleta de limitações.

\section{Referências}

BAKHTIN, Mikhail. Formas de tempo e de cronotopo no romance: ensaios de poética histórica. In: BAKHTIN, Mikhail. Questões de literatura e estética: a teoria do romance. Trad. (do russo): Aurora Fornoni Bernardini; José Pereira Júnior; Augusto Goés Júnior; Helena Spryndis Nazário; Homero Freitas de Andrade. São Paulo: Unesp, 1998. p. 211362.

Bíblia Sagrada: nova versão internacional / [traduzida pela comissão de tradução da Sociedade Bíblica Internacional]. 10. ed. São Paulo: Editora Geográfica, 2000.

BORGES FILHO, Ozíris. Bakhtin e o cronotopo: uma análise crítica. Revista Intertexto. Uberaba, UFMT, v. 4, n. 2, p. 50-67, jul./dez. 2011.

BORGES FILHO, Ozíris; BARBOSA, Sydney (orgs.). Poéticas do espaço literário. São Carlos: Editora Claraluz, 2008.

LINS, Osman. Espaço romanesco: conceitos e possibilidades. In: LINS, Osman. Lima Barreto e o espaço romanesco. São Paulo: Editora Ática, 1987. p. 62-76.

REIS, Carlos; LOPES, Ana Cristina Macário. Dicionário de teoria narrativa. São Paulo: Ática, 1988.

SARAMAGO, José. Caim. São Paulo: Companhia das Letras, 2009.

Recebido em junho de 2014.

Aceito em setembro de 2014. 